\title{
ОЧУВАЊЕ ЈЕЗИКА И КУЛТУРЕ У МУЛТИКУЛТУРНОЈ ЗАЈЕДНИЦИ
}

Савремено друштво из дана у дан постаје све више мултикултурално. Глобализација мења начин на који доживљавамо свој национални идентитет и културну припадност, а поред тога мења и начин на који доживљавамо друге људе, њихову културну припадност и идентитет. Питање мултикултуралности је постало у великој мери помодно питање и због тога са собом носи површност и непрецизност. Поред тога сведоци смо све веће асимилације култура и запостављања језика националних мањина. У мултикултуралним заједницама долази до пораста етно-језичких мешовитих бракова, што са собом повлачи питање васпитања и образовања деце из етно-језичких породица. Потребно је да припадници различитих култура изграде свој властити културни идентитет и да прихвате своју различитост, а након тога да науче да исто тако поштују и прихватају различитост других људи из своје заједнице. У раду се анализира мултикултурално и интеркултурално образовање у функцији очувања русинског језика и културе.

Кључне речи: мултикултуралност, језик, култура, национална мањина, русински језик, мултикултурално образовање, интеркултурално образовање

\section{УВОД}

Савремени свет и ново друштво све више брише јасне границе између култура, што временом води до културне асимилације. У склопу глобалног ширења долази до коренитих промена у традиционалној култури везаној за национални контекст која је временом почела да губи свој некадашњи углед. Глобализација указује и доказује да културни идентитети нису стални и коначни, него променљиви и динамични и да се налазе у сталном процесу промена и трансформација (Grandić, 2006). То не значи да треба дозволити културну асимилацију не недоминантних култура, која ће довести до њиховог стапања у друге културе, а временом и до њиховог нестајања. Важно је радити на изградњи свести о властитом културном идентитету и научити уважавати и прихватати различитости. На тај начин ће се формирати 
мултикултурално и интеркултурално компетентно друштво са усвојеним демократским вредностима у складу са стандардима за људска права.

\section{МУЛТИКУЛТУРАЛНОСТ}

Мултикултуралност се односи на плуралитет култура на једном простору и у једној заједници. Уколико се овај појам посматра из угла културне хетерогености, онда закључујемо да су сва људска друштва заправо мултикултурална. Међутим не треба да изузмемо чињеницу да нису сва друштва једнака, као што нису ни последице мултикултуралности идентичне у сваком од њих. Комплексно питање националних мањина се увек налази у позадини идеје мултикултуралности, што са собом повлачи и одређену потенцијалну опасност да се из неких разлога заоштре односи између мањина и већине. Идеолози мултикултуралне заједнице под појмом мултикултуралности подразумевају уважавање културног идентитета досељеника. Данашње модерне културе су међусобно испреплетане и прожимају се до те мере да се одређене навике и одлике живота не завршавају у границама националних култура, већ се оне налазе и у другим културама (Žarić, 1997). Културна интеграција подразумева суделовање у другој култури, али и утемељивање свести о властитом идентитету и културном наслеђу. Са друге стране, културна асимилација подразумева једнострани, неравноправни и наметнути процес утапања у нову културу без могућности да се очува властити идентитет и културно наслеђе предака. У литератури постоји разлика између мултикултуралности, мултикултурације и мултикултурализма. Мултикултуралност се односи на културни плурализам и подразумева основно и трајно обележје једног друштва. Мултикултурација подразумева процес који се формира на темељима идеје или идеала о толерантном, хармоничном, равноправном, испреплетаном и заједничком суживоту различитих култура и поткултура. Она би требало да се налази између културне асимилације и културне изолације, односно између две крајности базирајући се на принципима акултурације. На тај начин се процесом мултикултурације постиже потврђивање себе и прихватање других као равноправних, иако различитих. Мултикултурализам се односи на идеологију схваћену као систем идеја у којима се на прикривен начин изражава неки парцијални 
положај, интереси и вредности појединаца и друштвених скупина, а који се представљају као „општи“ друштвени интереси. У таквим ситуацијама он служи као покриће за остваривање неких идеолошкихполитичких циљева који могу чак да се супротстављају истинској мултикултурацији (Tripković, 2005).

У данашњем друштву доминира универзална масовна култура и у таквом друштву традиционална култура веома тешко долази до изражаја. Намеће се питање на који начин би требало у таквом друштву остварити идеал мултикултурације и ускладити снажну потребу модерног друштва за хомогеношћу са једне, а хетерогеношћу са друге стране. Социолози закључују да је Србија мултиетничка, али да је временом све мање мултикултурална, у смислу да је све мање локалних заједница у којима људи разумеју и користе језик својих комшија друге националности. Војводина је одувек била препозната као мултикултурална и позната по томе што су на овим просторима присутне различите културе. Када говоримо о русинској националној мањини њени припадници су се на ове просторе, у Бачку и Срем, доселила се пре око 260 година, након добијене подршке Хабзбуршке монархије. Њихова борба за национални и културни идентитет у Србији, почиње након пада Аустроугарске монархије када бивају одсечени од своје матице. Почетком 20. века основано је Русинско народно просветно друштво, а убрзо након тога је објављена и прва граматика русинског језика. Седамдестих година 20. века Русини добијају конститутивну једнакост са другим народима, са чиме русински језик постаје један од званичних језика Аутономне покрајине Војводине. Данас су Русини признати као посебна национална мањина са својим књижевним језиком. По попису Републичког завода за статистику из 2011. године, Русини чине $0,72 \%$ становништва Војводине, а њихова највећа концентрација, чак 60\% војвођанских Русина, налази се у општинама Кула и Врбас (Ilić, 2018).

\section{КУЛТУРА И ЈЕЗИК КАО ПЕЧАТ ДРУШТВА}

Култура се може одредити као образац понашања који се преноси из генерације у генерацију, затим као сложена целина знања, веровања, уметности, права, обичаја и свих других навика и способности које човек стиче у друштву, све до идеје колективно програмираног ума који разликује једно друштво од других. УНЕСКО је 
на конференцији о културној политици истакао да је култура та која појединцу даје способност да размишља о себи, јер човек кроз културу изражава себе, постаје свестан себе, препознаје своје недостатке, испитује своја достигнућа и неуморно трага за новим значењима стварајући дела са којима превазилази себе. Чињеница је да нас култура у великој мери чини управо онаквима какви јесмо (Zakić i Milutinović, 2014). Култура нас на одређени начин дефинише, издваја као појединца и даје одређени печат не само нама као појединцу, већ и друштву као глобалној институцији. Културни идентитет представља јединствен израз социјалног идентитета, с обзиром да је култура суштински део социјалног система и његова основа. Свака култура и супкултура је јединствена и посебна на свој начин и у оквиру сваке од њих постоје одређене комуникацијске норме и очекивања која се могу знатно разликовати од других. Сама култура једног народа има велику и важну улогу у учењу комуникацијских вештина, јер појединац управо кроз своју културу учи одређене концепте и ознаке кроз које посматра свет који га окружује (Miljković, 2015). Начин на који појединац комуницира, језик и језичке стилове које употребљава, као и одређено невербално понашање у великој мери су производ културе у којој је одрастао. Ипак, не треба да заборавимо чињеницу да постоје одређене разлике унутар једне културе, као и одређене индивидуалне разлике које никако нису занемарљиве.

C обзиром да је употреба језика главни начин очувања културног идентитета и да он представља круну једног народа и културе, остваривање језичких права је од великог значаја. Ова права обезбеђују боље услове очувања мањинских језика, а тиме и њиховог културног наслеђа (Dražović, 2018). Говор и језик су међусобно повезани и њихов однос се одређује као однос између општег и посебног, апстрактног и конкретног. Говор представља звучну конкретизацију језика, а језик је производ говора и остварује се у говору. Однос говора и језика је у потпуности условљен, јер језик не би постојао да нема могућност да се изрази у форми говора, а исто тако говор би нестао да не произилази из језика (Miljković, 2015). Кроз посматрање језика као организованог средства споразумевања увиђамо његову важну комуникативну улогу и примећујемо да је у великој мери друштвено условљен. Његова важност и значај потичу из чињенице да га појединац учи и користи у својој заједници са другим људима, кроз 
свакодневну комуникацију и интеракцију. На тај начин сви заједно утичу на развој и надоградњу језика и делују у сврси његовог очувања. Уколико језик посматрамо као оруђе којим појединац делује на свет који га окружује, можемо да приметимо да су сви језици на овом свету заправо једнаки и да имају једнаку вредност. Ипак, чињеница је да се у свакодневном животу одређени језици издвајају као мање или више доминантни. Оно што је важно да припадници мултикултуралне заједнице знају јесте да познавање једног језика не треба да угрожава развој другог и да познавање једног језика „више“ увек представља богатство особе која га познаје. На виталност језика утичу статусни, демографски, институционални и психолошки процеси друштва који се огледају у ставовима припадника мањина и већине у мултикултуралној заједници. Перспектива очувања једног језика се не може сагледати искључиво на основу статуса који тај језик има у заједници, односно на основу демографских и институционалних аспеката, већ је најчешће потребно ући и у срж психолошких процеса (Mikeš, 2001).

\section{МАТЕРЬИ ЈЕЗИК}

Матерњи језик је језик са којим се особа идентификује и он представља део особености. Појам матерњи језик потиче из латинског језика lingua materna и преводи се као “језик мајке”. На основу тога можемо закључити да се матерњи језик одређује према пореклу индивидуе, прецизније као језик којим говори наша мајка. Овакве дефиниције матерњег језика базирају се на идеји да индивидуа може да поседује само један матерњи језик, језик своје мајке. Међутим, матерњи језик не може и не треба у потпуности да се изједначава са језиком мајке, јер се ови појмови не налазе у истој појмовној равни. Матерњи језик може бити и језик оца, као и језик неког трећег лица или средине. Организација УНЕСКО матерњи језик дефинише као језик усвојен у раној доби, који спонтано постаје природни инструмент мишљења и комуницирања. Оваква дефиниција се повезује и са традиционалном дефиницијом, у којој се матерњи језик одређује као језик који појединац усваја још у најранијој доби, односно онај који мало дете добија на дар од својих родитеља. Дефиниција УНЕСКО-а из 1981. године истиче да појединац може да поседује два матерња језика, посебно уколико је одрастао у двојезичкој породици или двојезичној средини (PavlinićWolf, 1985). Од великог је значаја да дете добро научи свој матерњи 
језик, јер је то језик на којем особа касније размишља и осећа. То је језик са којим се особа идентификује и који јој даје културни идентитет.

Приликом одређивања и дефинисања матерњег језика издвајају се четири основна критеријума који представљају начин изучавања матерњег језика (Skutnab-Kangas, 1991): порекло, компетенција, функција и ставови. Критеријум порекла одређује матерњи језик као језик којим говори наша мајка, односно наши родитељи. Према овом критеријуму дете свој матерњи језик усваја током раног детињства и то је језик на којем се темељи дететова прва трајна комуникацијска веза. Обично се подразумева да породица говори једним језиком, али понекад родитељи говоре различитим језицима. Тада дете има могућност да паралелно усваја два матерња језика и постане изворни двојезични говорник. Следећи критеријум матерњи језик одређује као језик са којим се појединац најбоље служи. Понекада особа подједнако добро користи два језика и то су најчешће особе које су одрасле у двојезичним породицама, окружењу или су имале двојезично образовање. Критеријум функције подразумева примену одређеног језика и матерњи језик се посматра као језик којим се појединац најчешће служи. Ова дефиниција се не може у потпуности прихватити, јер су људи понекад приморани да се често служе језиком који не мора бити уједно и њихов матерњи језик и језик који они најбоље познају. Последњи критеријум односи се на став особе, па се матерњи језик дефинише као језик са којим се особа идентификује. У том случају идентификација може да буде унутрашња и спољашња, односно језик са којим појединац сам себе идентификује и језик према коме га други људи идентификују. Приликом овог критеријума се може десити да особа у једној ситуацији буде идентификована као изворни говорник једног, а у другој ситуацији као изворни говорник другог језика.

Према неким другим ауторима (Mikeš, 2000) матерњи језик је језик који дете усваја најкасније до четврте године, а сви језици које дете усваја након тог периода дефинишу се као нематерњи језици. Под нормалним околностима свако дете је способно да у периоду до четврте године усвоји све битне елементе и правила матерњег језика. Уколико у том периоду дете има прилику да у кругу породице или најближе околине комуницира на различитим језицима, тада оно постаје изворни двојезични, а некада и вишејезични говорник. Деца у периоду раног детињства језике усвајају спонтано кроз свакодневну комуникацију и 
интеракцију са људима из своје околине. Брзина усвајања нематерњег језика зависи пре свега од језичког окружења, тако деца која усвајају језик средине и свакодневно улазе у комуникацију и интеракцију на свом не матерњем језику, веома брзо и успешно усвајају исти. Ипак, битно је узети у обзир и индивидуалне склоности детета, а не само услове подстицајне средине.

\section{ОБРАЗОВАЮЕ НАЦИОНАЛНИХ МАЮИНА НА ЮИХОВОМ МАТЕРЬЕМ ЈЕЗИКУ}

У Моделу закона о заштити права националних мањина у Србији наводи се да је национална мањина свака група држављана Србије која представља бројчану мањину на њеној територији и чији припадници имају свест о етничкој, језичкој, националној или културној посебности коју су спремни да негују и одржавају. Према закону постоје три опције образовања на језику националне мањине: (1) у потпуности на језику националне мањине, (2) двојезично и (3) кроз изучавање језика националне мањине са елементима националне историје и културе. Међутим у образовној пракси националних мањина не постоји опција двојезичног образовања, обично је то или на језику мањине или на језику већине и факултативно похађање језика мањине са елементима националне историје и културе. Надлежни орган утврђује минималан број ученика и тај број у случају образовања националних мањина може да буде мањи од минималног броја ученика који је законом прописан. Образовање на језику националне мањине подразумева обавезно учење српског језика у обиму којим се обезбеђује савладавање тог језика. Хетерогене друштвено-политичке заједнице могу се организовати по принципу “један језик, једна нација". У том случају се деца образују на матерњем језику, све док је то могуће. Међутим тада постоји ризик да деца тешко овладају језиком државе, а да добро говоре само свој матерњи језик. У друштвено-политичким заједницама плуралистичког типа, избор језика школовања детета представља деликатан проблем, посебно када се ради о мањинском статусу језика. Тада се јављају различите могућности, тако да уколико је језик породице или једног од родитеља већински, дете се најчешће школује на језику већине, а уколико је језик породице мањинског статуса у некој средини дете се најчешће школује на свом матерњем језику, док касније у току даљег школовања прелази на језик већине. 
Када говоримо о образовању деце русинске националне мањине сада постоје три основне школе у Војводини са русинским одељењима, са тенденцијом да се тај број смањи због све мањег броја деце. Према подацима Националног пописа из 2011. године утврђено је да је број русинске популације у Србији опадању $(-10,43 \%)$. Почеци школског образовања на русинском језику започели су половином 18. века у Руском Крстуру и Куцури, а почетком 20. века означени су почеци предшколског образовања на русинском језику. У Руском Крстуру од 1970. године постоји и гимназија „Петро Кузмјак“ која обезбеђује средњошколско образовање на русинском језику и то је једина средња школа у свету у којој постоји опција образовања на русинском језику. У склопу гимназије постоји и интернатски смештај и тако да ову школу могу да похађају и деца која су из других земаља где живе Русини. Убрзо након отварања русинске гимназије „Петро Кузмјак“ основан је и Лекторат за русински језик на Филозофском факултету у Новом Саду, а 1981. године Катедра за русински језик и књижевност (Fejsa, 2010). Изазов са којима се сусреће русинска мањина у сектору образовања, јесте мала бројност заједнице и културна асимилација. Поред тога, већина родитеља процењује да се шансе за боље запослење и економски просперитет њихове деце налазе у адекватном знању и познавању српског језика, што доводи до потпуног запостављања русинског језика (Petsinis, 2004).

\section{ПРЕМА ИНТЕРКУЛТУРАЛНОМ ОБРАЗОВАњУ}

Образовање би требало да одговори на потребе и захтеве савременог друштва и да створи повољну климу у којој ће сваки појединац имати осећај подједнаке припадности заједници. Оно би требало да буде једнако доступно свима који желе и који су способни да стекну образовање. То се односи на једнако право свих без обзира на њихов пол, узраст, социјални положај, религију, националну припадност и слично (Milutinović, 2008). Интеркултурално образовање настоји да реформише мишљење и учење о различитостима вреднујући могућности разлика. Оно има значајну улогу у подучавању о културним различитостима и треба да створи нови концепт учења у којем ће културне разлике бити прихваћене као средство трансформације будућности. У савременом свету културне разноврсности од образовних институција се очекује да постану другачије, јер су и данашњи ученици 
другачији. Интеркултурално образовање има улогу да припреми ученике и младе људе за ефикасно функционисање у 21. веку. У образовним институцијама је потребно створити простор у којем ће сваки појединац, без обзира на националну припадност, имати могућност да изразе себе, своје искуство и идеје помоћу својих речи и облика представљања (Grandić, 2006). Потребно је да се афирмише интеркултуралност и интеркултурално образовање као полазна оријентација, доминантан приступ и кључна смерница васпитања и образовања. Циљ је да се уз помоћ образовања друштво врати култури, јер када појединац стекне свест о властитој култури он учи да прихвата и друге културе (Đukić, Đermanov i Kosanović, 2013). Интеркултуралност истиче и наглашава однос између култура и неопходност ьихове интеракције. Она подразумева могућност упоређивања мишљења, подстиче на размишљање о разликама, омогућава комуникацију и упознавање различитости. Она подразумева отвореност према другим културама, могућност сагледавања из туђе перспективе и способност суочавања у сложеним и нејасним ситуацијама. Примењујући овај концепт у наставном процесу, он омогућава да се наставници и ученици упознају са разликама, да прихвате и изграде свој културни идентитет, али и да постану толерантнији према културним разликама и прихвате културу других. Овакав концепт образовања доводи до сузбијања различитих предрасуда и стереотипа у мултикултуралним заједницама (Vidosavljević, Vidosavljević i Krulj-Drašković, 2016).

Интеркултурални концепт у образовању и васпитању појавио се у Западној Европи 1975. године као могући модел за који се претпоставља да ће помоћи у превазилажењу проблема мултикултуралног састава европског друштва. У Републици Србији правни оквир и основу за интеркултурално образовање чине међународни инструменти. Као део процеса европских интеграција у Србији, 2017. године отворено је Поглавље које се тиче образовања, културе, спорта и омладине. Хармонизацијом прописа у области образовања и културе отварају се и могућности за интеграцију интеркултуралног образовања у образовни систем Србије (Beara i dr. 2018: 83). Овај рад тежи да овој интеграцији да свој допринос. С обзиром да се у Националној стратегији Русина до 2020. године (Vislavski i dr., 2013) уопште не помиње интеркултуралност, у нову 
стратегију би је требало унети. Подсећамо да је један од циљева образовања и васпитања „развијање личног и националног идентитета, развијање свести и осећања припадности Републици Србији, поштовање и неговање српског језика и матерњег језика, традиције и културе српског народа и националних мањина, развијање интеркултуралности, поштовање и очување националне и светске културне баштине“ (Vlada Republike Srbije, 2017). У оквиру русинске националне заједнице не налазимо монографије на тему интеркултуралности, а научноистраживачки радови су се појавили тек у новије време на конференцијама ИнтерКулт Педагошког завода Војводине које се организују од 2015. године.

\section{ЗАКљУЧАК}

Војводина је мултикултурална заједница и у таквој заједници деца се већ од првих интеракција у кругу породице и у непосредном окружењу, укључују у комуникацију на два, па и више језика. У заједницама које промовишу социјалну укљученост свих, а различитост посматрају као потенцијал, нарочита пажња се поклања процесима који доприносе очувању и суживоту различитих култура.

У мултикултуралним заједницама због комплексности и противречности многа питања остају још увек отворена. Паралелни процес глобализације и мултикултурализма повећава кризу културе и очувања језика, што све са собом повлачи кризу културног идентитета. То се односи и на русински језик и русински културни идентитет. Пред образовну политику стављају се велика очекивања и изазови, а решење се види у интеркултуралном образовању и образовним реформама које делују у циљу очувања култура. Не треба дозволити да време у коме се налазимо доведе од асимилације култура и нестанка језика и традиције мањинских народа. Стога образовање има задатак да припреми и научи ученике да као одрасли чувају своју културу и свој језик. Уколико желимо да постигнемо мир потребно нам је холистичко образовање, мултикултурално и интеркултурално образовање. Кључ успеха лежи управо у образовању које може утицати на промене у целом друштву. 


\section{ЛИТЕРАТУРА}

Beara, M.-Bu, A. \& Savić, S. (2018). Obuka interkulturalnog obrazovanja nastavnika u Srbiji - iskustva i rezultati (2013-2017). U: Spariosu, L., Ivanić, I., Petković, V. (ured.) (2018). InterKult 2017, vol. 1. Novi Sad: Pedagoški zavod Vojvodine, Filozofski fakultet. 81-100

Dražković, B. (2019). Etnologistična vitalnosc rusкoho jazika u Serbiji. Novi Sad: Zavod za kulturu vojvodjanskich Rusnacoch. (Cyrillic)

Đukić, M.-Đermanov, J. \& Kosanović, M. (2013). Pedagogija različitosti: za dijalog kultura u inkluzivnoj školi. U: Živančević Sekeruš, I. (ured.) (2013). Susret Kultura - Šesti međunarodni interdisciplinarni simpozijum (1). Novi Sad: Filozofski fakultet. 191-200. Preuzeto sa http://digitalna.ff.uns.ac.rs/sadrzaj/2013/978-86-6065-184-8 (Cyrillic)

Fejsa, M. (2010). Nova Srbija i njena rusinska manjina / Nova Serbija i jej ruska menšina/ The New Serbia and Its Ruthenian Minority. Novi Sad: IK Prometej, KPD DOK.

Grandić, R. (2006). Globalizacija i obrazovanje. Novi Sad: Savez pedagoških društava Vojvodine. (Cyrillic)

Ilić, N. (2019). Etnolingvističko istraživanje Rusina u Vojvodini. U: Ramač, Ja., Petković V. \& Mudri, A. (ured.) (2019). InterKult 2018. Novi Sad: Pedagoški zavod Vojvodine, Univerzitet u Novom Sadu Filozofski fakultet - Odsek za rusinistiku, 77-95.

Mikeš, M. (2000). Dete u svetu dvojezičnih čarolija: priručnik za roditelje $i$ prosvetne radnike. Veternik: LDIJ.

Mikeš, M. (2001). Kad su granice samo tarabe: istraživanja višejezičnosti u Vojvodini. Novi Sad: Jugoslovensko društvo za primenjenu lingvistiku, Futura publikacije.

Milutinović, J. (2008). Ciljevi obrazovanja i učenja u svetlu dominantnih teorija vaspitanja 20. veka. Novi Sad: Savez pedagoških društava Vojvodine.

Miljković, M. (2015). Jezik i kultura. U: Minić, S. (ured.) (2015) Zbornik radova Učiteljskog fakulteta Prizren-Leposavić, (9). Leposavić: Univerzitet u Prištini - Učiteljski fakutlet. 153-164. Preuzeto sa https://scindeks.ceon.rs/article. aspx ?artid=1452-93431509153M (Cyrillic) 
Pavlinić-Wolf, A. (1985). Definicije materinskog jezika i s njima povezani problemi. Migracijske i etničke teme, 1(3-4), 57-68. Preuzeto sa https://hrcak.srce.hr/128938

Petsinis, V. (2004). Vojvođanske nacionalne manjine - sadašnje stanje i budući izgledi. Sociološki pregled, 38(1-2), 219-237. (Cyrillic)

Skutnab-Kangas, T. (1991). Bilingvizam: da ili ne. Beograd: Zavod za udžbenike i nastavna sredstva.

Tripković, M. B. (2005). Multikulturalnost, multikulturacija i prava manjina. Sociološki pregled, 39(1), 81-95. (Cyrillic)

Vidosavljević, S.-Vidosavljević, M. \& Krulj-Drašković, J. (2016). Interkulturalna nastava u vaspitno-obrazovnom procesu. Zbornik radova Učiteljskog fakulteta Prizren-Leposavić, (10), Leposavić: Univerzitet u Prištini - Učiteljski fakultet. 185-201. Preuzeto sa https://scindeks.ceon.rs/article.aspx?artid=1452-93431610185V (Cyrillic)

Vislavski, B.-Fejsa, M.-Kišjuhas Ja. \& dr. (2013). Nacionalna strategija Rusnacoch/ Nacionalna strategija Rusina / The National Strategy of the Ruthenians. Novi Sad: Nacionalni sovit ruskej nacionalnej menšini, NVU Ruske slovo. (Cyrillic)

Vlada Republike Srbije. (2017). Zakon o osnovama sistema obrazovanja $i$ vaspitanja. Beograd: Službeni glasnik RS.

Zakić, K. \& Milutinović, O. (2014). Kulturni konflikti u uslovima globalizacije. Godišnjak Fakulteta za kulturu i medije: komunikacije, mediji, kultura, 6 (6), 487-507. Preuzeto sa https://scindeks.ceon.rs/article.aspx?artid=1821-01711406487Z (Cyrillic)

Žarić, M. (1997). Multikulturalnost - nastojanje ili himba? (Analiza pojma na primjeru Njemačke). Revija za socijalnu politiku, 4 (2), 139-148. Preuzeto sa https://hrcak.srce.hr/29870

Jasmina Klemenović, Dorotea Budinski

PRESERVATION OF LANGUAGE AND CULTURE IN A MULTICULTURAL COMMUNITY

\section{Summary}

The current world is becoming more and more multicultural. As part of global expansion, there are radical changes in the traditional culture related to the national 
context, which has begun to lose its former reputation. Globalization is changing the way we experience our cultural identity and the way we experience the cultural belonging of other people. The parallel processes of globalization and multiculturalism increase the crisis of culture, as well as the cultural identity crisis. We are witnessing the assimilation of cultures. Members of different cultures must build their cultural identity, accept their diversity, and learn to respect other cultures. The process of belonging to a community doesn't imply ignoring cultural differences, nor cultural assimilation. Education plays a significant role in all this. There is a need to reform education for interculturalism and to prepare teachers for a new concept of education.

The paper analyzes multicultural and intercultural education in the function of preserving the Ruthenian language and culture.

Key words: multiculturalism, language, culture, minorities, Ruthenian language, multicultural education, intercultural education 
